Katarzyna Kubiszewska (iD) https://orcid.org/0000-0001-7446-5407

Politechnika Gdańska

kku@zie.pg.gda.pl

Marta Szeluga-Romańska (iD https://orcid.org/0000-0002-7383-5709

Politechnika Gdańska

msr@zie.pg.gda.pl

\title{
Biblioteka w nowym świecie czy nowy świat w bibliotece?
}

Abstract

\section{A Library in a New World or a New World in a Library?}

Due to the profound changes in the modern world, the role of a contemporary library is also not what it used to be. The paper presents new various roles fulfilled by libraries in the 21st century, showing that, in the current reality, measuring the effectiveness of a library only quantitatively oversimplifies the issue and does not do justice to the socially complex function of this cultural institution. Based on the quantitative and qualitative research, the author attempts to specify certain elements of the future role of a library, indicate how the library performance evaluation systems should be improved, and suggest his own original method of measuring the library total value and performance.

Keywords: library, efficiency, effectiveness, qualitative research, quantitative research

Słowa kluczowe: biblioteka, efektywność, skuteczność, badania jakościowe, badania ilościowe 


\section{Wprowadzenie}

W roku 1983 japoński socjolog Yoneji Masuda próbował przewidzieć przyszłość biblioteki. Na podstawie obserwacji pewnych zachowań i trendów społecznych, przede wszystkim nadchodzącej wówczas ery społeczeństwa informacyjnego, uznał, że zasadnicze zmiany w postrzeganiu bibliotek nastąpią poprzez trzy wymiary transformacji: dyfuzję technologii informatycznej, (która spowoduje) zmiany systemów społecznych oraz - w konsekwencji - zmiany ludzkich potrzeb [Masuda 1983]. Jaka miała być biblioteka przyszłości? Po pierwsze, zautomatyzowana, wyposażona w cyfrowe zasoby, z których użytkownicy będą mogli korzystać na odległość, a w której nie będzie już pracowało zbyt wielu bibliotekarzy. Po drugie, będzie miała użyteczność bibliograficzną w skali światowej. Będzie również miejscem przechowywania historycznych zapisów dotyczących ludzkości. Po trzecie, zasadniczo zmieni się rola bibliotekarza. Będzie on wykonywał pracę bardziej intelektualną, badawczą. Stanie się pewnego rodzaju ekspertem i „dostarczycielem” wiedzy skoncentrowanej na celu istotnym dla użytkowników, odpowiadając na ich różnorodne potrzeby. Będzie również współpracował $\mathrm{z}$ autorami i wydawcami, m.in. w celu upewnienia się, czy ich praca jest zintegrowana $z$ konkretnym zapotrzebowaniem na wiedzę, a wszystko pod kontrolą scyfryzowanej bibliografii. Odpowiedzialność pracy bibliotekarzy przyszłości będzie dużo wyższa [ibidem].

Jak bliski prawdy był Yoneji Masuda? Jak wygląda dzisiejsza biblioteka i jaka będzie jej przyszłość? Celem niniejszego artykułu jest zaprezentowanie nowych różnorodnych form działania, podjętych przez społeczną instytucję, jaką jest biblioteka, które pojawiły się jako efekt wielu głębokich zmian we współczesnym świecie. A także pokazanie, że w takim stanie rzeczy mierzenie efektywności bibliotek jedynie miernikami ilościowymi jest spłycaniem ich szerokiego działania i nie oddaje ich złożonej społecznie funkcji. Na podstawie przeprowadzonych badań zostaną zaprezentowane także pewne elementy przyszłej roli biblioteki oraz wskazane kierunki rozwoju systemów oceny działania bibliotek.

Artykuł został podzielony na trzy części. W pierwszej z nich, na podstawie literatury przedmiotu, przeprowadzono dyskusję zarówno w odniesieniu do zmieniającej się roli bibliotek, jak również do metod oceny działania bibliotek. W drugiej części zaprezentowano wyniki badań empirycznych, by w części trzeciej pokusić się o zaprezentowanie autorskiej koncepcji działania bibliotek wraz z metodami oceny w przyszłości. 


\section{Zmieniająca się rola biblioteki a wskázniki oceny jej dzialania - przeğląd literatury}

„Biblioteka to zbiór zasobów w różnych formatach, który jest organizowany przez specjalistów informacji lub innych ekspertów, zapewniających wygodny fizyczny oraz cyfrowy dostęp i oferujących ukierunkowane usługi i programy z misją edukacji, informowania lub rozrywki dla różnych grup odbiorców oraz w celu stymulowania indywidualnego uczenia się i rozwoju społeczeństwa jako całości” [Eberhart, $2010]^{1}$. Oznacza to, że biblioteka publiczna, podmiot założony i finansowany przez instytucję rządową, różnego szczebla, musi być dostępna dla wszystkich chętnych do korzystania, bez uprzywilejowania i dyskryminacji. Podstawą prawną funkcjonowania bibliotek w Polsce jest Ustawa z dnia 27 czerwca 1997 roku o bibliotekach (Dz.U. 1997 nr 85 poz. 539) oraz Ustawa z dnia 25 października 1991 roku o organizowaniu i prowadzeniu działalności kulturalnej (Dz.U. $1991 \mathrm{nr} 114$ poz. 493). Artykuł 18.1. ustawy o bibliotekach wskazuje, że celem bibliotek publicznych jest zaspokajanie potrzeb oświatowych, kulturalnych i informacyjnych ogółu społeczeństwa oraz udział w upowszechnianiu wiedzy i kultury.

$\mathrm{Z}$ jednej strony stopień realizacji celów przez biblioteki świadczy o ich znaczeniu w społeczeństwie. $Z$ drugiej jednak każda biblioteka może pełnić jedną lub więcej funkcji jednocześnie, zaspokajając różnorodne potrzeby różnych grup społecznych użytkowników. Jak pisze Laura Juchnevič [2014], wraz ze zmieniającym się dynamicznie społeczeństwem zmieniają się także role wszelkich instytucji społecznych, w tym również bibliotek. Autorka zauważa zmiany (głównie jakościowe) w środowiskach: technologicznym, ekonomicznym, społecznym, kulturowym oraz infrastruktury informacji, które niewątpliwie - w mniejszym lub większym stopniu - dotykają biblioteki. Według Tarvindera Singh Handy [2015] biblioteka publiczna pełni następujące funkcje: umożliwianie dostępu do narzędzi informacji i edukacji, funkcja instrumentalna w nieformalnym samodokształcaniu, promowanie kulturalnych i społecznych aktywności, przechowywanie lokalnych wytworów kulturowych, wzmacnianie ducha demokracji. Z kolei Juchnevič [2014] zauważa [za: Thorhauge, Larsen, Thun, Albrechtsen 1997], że biblioteki, oprócz oczywistej roli edukacyjnej i informacyjnej, odgrywają także role centrów kultury oraz dają schronienie (różnym grupom).

Według koncepcji Marca Prensky’ego [2001] współczesne społeczeństwo można podzielić na dwie zasadnicze grupy - na „cyfrowych imigrantów” i „cyfrowych tubylców”2. Pierwsi urodzili się w czasach, gdy technologie cyfrowe nie istniały lub nie były tak powszechne. Musieli się ich nauczyć w nieco późniejszym wieku, nie do

1 Tłumaczenie własne.

2 Prób podziału społeczeństwa na różniące się od siebie grupy jest dużo więcej, chociażby na Generację X, Y, lecz autorki zdecydowały się przywołać tylko koncepcję Prensky’ego, jako tę najbardziej przejrzystą i jednoznaczną. 
końca rozumiejąc ich zasięg i możliwości. Druga grupa, czyli „tubylcy”, urodzili się w świecie wszechobecnych technologii cyfrowych i biegle potrafią się nimi posługiwać. Tabele 1 i 2 pokazują, jak kształtują się współczesne role bibliotek w zależności od zmieniających się potrzeb obu opisanych grup społecznych z nich korzystających.

Tabela 1. Imigranci cyfrowego świata a biblioteki

\begin{tabular}{|l|l|l|l|l|}
\cline { 2 - 5 } \multicolumn{1}{c|}{} & \multicolumn{2}{c|}{ OTOCZENIE } \\
\cline { 2 - 5 } \multicolumn{1}{c|}{} & \multicolumn{1}{c|}{ ekonomiczne } & \multicolumn{1}{c|}{ społeczne } & \multicolumn{1}{c|}{$\begin{array}{c}\text { infrastruktura } \\
\text { informacji }\end{array}$} \\
\hline $\begin{array}{l}\text { imigranci } \\
\text { cyfrowego } \\
\text { świata }\end{array}$ & $\begin{array}{l}\text { używanie współczes- } \\
\text { nych technologii } \\
\text { w pracy, zamawianiu } \\
\text { usług, produktów, } \\
\text { pojawiających się } \\
\text { alternatywnych form } \\
\text { spędzania czasu } \\
\text { wolnego }\end{array}$ & $\begin{array}{l}\text { zmiany na rynku } \\
\text { pracy: zanikanie za- } \\
\text { zodów, praca z domu, } \\
\text { dzeniany w wynagro- }\end{array}$ & $\begin{array}{l}\text { niska liczba urodzeń, } \\
\text { wysoki odsetek } \\
\text { rozwodów, emigracja } \\
\text { itd., zanikanie hie- } \\
\text { rarchii w strukturach } \\
\text { społecznych }\end{array}$ & $\begin{array}{l}\text { ulepszenie przepływu } \\
\text { informacji, potrzeba } \\
\text { biegłości cyfrowej, } \\
\text { potrzeba posiadania } \\
\text { wiedzy, jak wybrać } \\
\text { odpowiednią i war- } \\
\text { tościową informację }\end{array}$ \\
\hline $\begin{array}{l}\text { role } \\
\text { biblioteki }\end{array}$ & $\begin{array}{l}\text { ogniwo pośredniczące pomiędzy informacją a wiedzą, stymulator edukacji (również przez całe } \\
\text { życie), dostarczyciel zarówno codziennych, jak i wyjątkowych informacji, edukator biegłości } \\
\text { cyfrowej itd. }\end{array}$ \\
\hline
\end{tabular}

Źródło: Juchnevič 2014: 8 na podstawie: Pilcher 1994; Meister, Willyerd 2010; Levickaitè 2010; Prensky 2001; Selwyn 2009; Lee 2012; Rudzkienė, Černikovaitè 2012; Laužikas 2013 (tłum. własne).

Tabela 2. Tubylcy cyfrowego świata a biblioteki

\begin{tabular}{|c|c|c|c|c|}
\hline & \multicolumn{4}{|c|}{ OTOCZENIE } \\
\hline & techniczne & ekonomiczne & społeczne & $\begin{array}{l}\text { infrastruktura } \\
\text { informacji }\end{array}$ \\
\hline $\begin{array}{l}\text { tubylcy } \\
\text { cyfrowego } \\
\text { świata }\end{array}$ & $\begin{array}{l}\text { intensywne użytko- } \\
\text { wanie współczes- } \\
\text { nych technologii, } \\
\text { alternatywne formy } \\
\text { spędzania czasu } \\
\text { wolnego, potrzeba } \\
\text { nowych technologii } \\
\text { i ich umocnienie }\end{array}$ & $\begin{array}{l}\text { wybór profesji (po- } \\
\text { pularnych profesji), } \\
\text { potrzeba wyższej } \\
\text { edukacji, wizja i pla- } \\
\text { nowanie przyszłości }\end{array}$ & $\begin{array}{l}\text { zmiany w strukturze } \\
\text { rodziny, integracja } \\
\text { ze społeczeństwem, } \\
\text { zmiany w postawie } \\
\text { wobec edukacji, } \\
\text { wybiórcza percepcja } \\
\text { świata, używanie } \\
\text { elementów sieci } \\
\text { społecznych }\end{array}$ & $\begin{array}{l}\text { zdolność do przetwa- } \\
\text { rzania, analizowania } \\
\text { i używania dużych } \\
\text { ilości informacji, } \\
\text { zaufanie w powszech- } \\
\text { ne źródła informacji, } \\
\text { które są tworzone } \\
\text { przez społeczeństwo }\end{array}$ \\
\hline $\begin{array}{l}\text { role } \\
\text { biblioteki }\end{array}$ & \multicolumn{4}{|c|}{$\begin{array}{l}\text { skupienie się na aktywnościach społecznych i kulturalnych, przestrzeń społeczna, „trzecie miej- } \\
\text { sce”, schronienie dla grup wrażliwych społecznie (np. dla dzieci), część systemu edukacyjnego, } \\
\text { stymulator edukacji na przestrzeni życia itd. }\end{array}$} \\
\hline
\end{tabular}

Źródło: Juchnevič 2014: 8 na podstawie: Pilcher 1994; Meister, Willyerd 2010; Levickaitè 2010; Prensky 2001; Selwyn 2009; Lee 2012; Rudzkienè, Černikovaitè 2012; Laužikas 2013 (tłum. własne). 
W związku ze zmieniającym się modelem funkcjonowania bibliotek publicznych w społeczeństwie, niezbędna jest analiza ich działania. Nie jest to nowe zagadnienie. Już od początku XX wieku temat ten budził zainteresowanie, a szczególnie aktywnie rozwijał się od lat 60. XX wieku [Głowacka 2015]. Celem funkcjonujących międzynarodowych norm: ISO 11620 (Information and Documentation - Library performance indicators), ISO 2789 (Information and Documentation - International library statistics) oraz - ISO 16439 (Information and documentation - Methods and procedures for assessing the impact of libraries), jest bieżące monitorowanie działania bibliotek, jak również ocena jakości i efektywności zasobów i usług bibliotecznych oraz innych działań prowadzonych przez biblioteki i ich wpływu na otoczenie.

Do oceny bibliotek służą wskaźniki efektywności i skuteczności. Niestety, w literaturze przedmiotu nie zdefiniowano jednoznacznie tych pojęć w kontekście bibliotek. O ile są one od dawna stosowane i, mimo swojej złożoności, klarownie zdefiniowane w odniesieniu do sektora przedsiębiorstw, o tyle nie wydaje się, by ich bezpośrednia adaptacja dla celów oceny działania bibliotek była wskazana. Przede wszystkim jest to związane z odmiennymi celami każdej z tych instytucji. W przypadku przedsiębiorstwa jest to wzrost jego wartości, a także rosnąca zyskowność oraz oczekiwane rosnące przepływy dla właścicieli i permanentne utrzymywanie płynności. W przypadku bibliotek jednak - cel ich działalności nie jest wyrażony w miernikach pieniężnych, a koncentruje się na zagadnieniach społecznych.

Najczęściej efektywność bibliotek rozumiana jest jako „relacja między nakładami a poziomem świadczonych przez bibliotekę usług" [Górny 1999: 40], co jest zbieżne z definicją efektywności używaną w odniesieniu do podmiotów komercyjnych. Efektywność to również „zdolność do bieżącego i strategicznego przystosowania się do zmian w otoczeniu oraz produktywnego i oszczędnego wykorzystania posiadanych zasobów dla realizacji przyjętej struktury celów" [Penc 1997: 100]. Efektywność jest utożsamiana z miarą stopnia, w jakim realizowane są dane cele, sytuując ją jako element podrzędny (miernik) w stosunku do pojęcia skuteczności [Biliński 2002: 7], która jest uznawana za jeden z głównych mierników funkcjonowania bibliotek [Zybert 2005: 2-8]. Z kolei skuteczność należy rozumieć jako podejmowanie odpowiednich działań dla osiągania założonych celów. W przypadku bibliotek cele nie mogą być wyrażone w sposób pieniężny, gdyż głównym założeniem działania tych instytucji jest realizacja założeń wyżej wymienionego artykułu 18.1 ustawy o bibliotekach.

Jednakże ze względu na ich publiczny charakter i związany z tym model finansowania ze środków jednostek samorządu terytorialnego (JST), w literaturze przedmiotu pojawiają się badania nad efektywnością finansową i kosztową bibliotek. Analiza zwrotu z inwestowania w bibliotekę, której efektem jest wyrażanie wartości usług bibliotecznych w jednostkach monetarnych, może budzić kontrowersje [Grygrowski 2014: 166-188]. Stosuje się także ekonometryczne metody modelowania kosztów, które wskazały na możliwość utrzymania skali działalności większości bibliotek przy nieznacznej tylko redukcji kosztów płacowych i zakupu zbiorów 
[Osiewalski, Osiewalska 2002; Prędki 2015]. Trzeba zaznaczyć, że wielkość i źródła finansowania bibliotek w Polsce zmieniają się, co wynika głównie z podziału zadań między państwem a jednostkami samorządu terytorialnego w odniesieniu do całego sektora kultury. O ile na początku transformacji środki przeznaczane na finansowanie bibliotek $\mathrm{z}$ budżetów jednostek terytorialnych i centralnych były relatywnie podobne, o tyle od 1996 roku, w związku z przejęciem przez samorządy większości zadań o charakterze kulturalnym, nastąpiło dostosowanie mechanizmów finansowania. Skutkowało to sukcesywnym wzrostem udziału i samodzielności samorządów w finansowaniu bibliotek [Budyńska, Jezierska 2011].

Kwestią otwartą pozostaje zagadnienie osiągnięcia efektywności finansowej biblioteki w połączeniu z realizacją jej celów, szczególnie w kontekście zmieniającej się jej roli. Należy zaznaczyć, że działanie bibliotek powinno być rozpatrywane wielopłaszczyznowo, uwzględniając aspekty zarządzania, poziomu kwalifikacji zawodowych bibliotekarzy, stosowane normy i metody działania, a także wyposażenie techniczne. A skutkiem tak działającej biblioteki powinien być rosnący „wskaźnik czytelnictwa”, czyli udział mieszkańców, z obszaru obsługiwanego przez bibliotekę, korzystających z jej zbiorów [Wołosz 2002].

\section{Metody badania}

Część empiryczna artykułu ma na celu ocenę poziomu kształtowania się czytelnictwa w kontekście zmieniającego się modelu funkcjonowania bibliotek. Badanie przeprowadzono dwuetapowo. Najpierw wyodrębniono czynniki oddziałujące na poziom czytelnictwa i przy wykorzystaniu metod ilościowych przeprowadzono analizę ich oddziaływania. Następnie, posługując się metodami jakościowymi, oceniono zmianę modelu działania bibliotek i jej wpływ na poziom czytelnictwa.

Badanie zostało przeprowadzone na podstawie danych za okres 1999-2016, zebranych dla czterech bibliotek - samorządowych instytucji kultury zlokalizowanych w Krakowie. Są to: Krowoderska Biblioteka Publiczna, Nowohucka Biblioteka Publiczna, Podgórska Biblioteka Publiczna oraz Śródmiejska Biblioteka Publiczna, które do końca 2016 roku funkcjonowały jako samodzielne jednostki. Działały one w obrębie ogólnokrajowej sieci bibliotek publicznych. Od 1 stycznia 2017 roku w wyniku ich połączenia, na mocy decyzji Rady Miasta Krakowa, powstała Biblioteka Kraków, która stanowi jedną samorządową jednostkę organizacyjną Gminy Miejskiej Kraków. Nowa instytucja prowadzi działalność statutową za pośrednictwem 57 bibliotek filialnych, funkcjonujących pod dotychczasowymi adresami. Zakres działania nowo powstałej instytucji nie różni się od zadań stawianych wcześniej poszczególnym bibliotekom. Jest to rozwijanie i zaspokajanie oświatowych, kulturalnych i informacyjnych potrzeb społeczeństwa oraz upowszechnianie czytelnictwa i kultury. W celu wyeliminowania ewentualnych zniekształceń związanych 
ze zmianą organizacyjną funkcjonowania bibliotek badanie w części empirycznej, przeprowadzone przy wykorzystaniu narzędzi o charakterze jakościowym, jak i ilościowym, zakończono na roku 2016.

Do opisu zebranych danych posłużono się analizą statystyczną i ekonometryczną, skupiając się na zmianach wielkości woluminu, liczby czytelników oraz liczby wypożyczeń, a także wielkości dotacji w każdej z wyżej wymienionych bibliotek. W celu pogłębienia badania stworzono wskaźniki dla przedstawienia skuteczności działań podejmowanych przez poszczególne biblioteki. Są to wskaźniki: wielkość dotacji na jednego czytelnika, liczba wypożyczeń jednego czytelnika, liczba wypożyczeń jednego woluminu oraz liczba woluminów przypadająca na jednego czytelnika. Ich wspólna analiza może być traktowana jako analiza skuteczności działania bibliotek.

W kolejnych etapach oceniono zależność poziomu czytelnictwa od wielkości dotacji oraz liczby woluminów i liczby czytelników. W tym celu sprawdzono hipotezę badawczą, mówiącą o występowaniu związku pomiędzy tymi zmiennymi. W celu doboru metod statystycznych dokonano porównania rozkładów analizowanych zmiennych z rozkładem normalnym za pomocą testu Kołmogorowa-Smirnowa. Do oceny siły i kierunku związku pomiędzy poszczególnymi zmiennymi ilościowymi zastosowano współczynnik korelacji $r$-Pearsona (dla zmiennych o rozkładzie normalnym). W całym opracowaniu dla celów obliczeń przyjęto istotność statystyczną na poziomie współczynnika $\mathrm{p}<0,05$.

Dla oceny wpływu poszczególnych zmiennych na poziom czytelnictwa mierzonego liczbą wypożyczeń uwzględniono standardowe metody wnioskowania ekonometrycznego, przy zastosowaniu panelowych modeli danych. Wykorzystano modele z efektami stałymi, w przypadku których standardowymi technikami estymacji są metoda najmniejszych kwadratów (MNK, estymator wewnątrzgrupowy) i szacowana uogólniona metoda najmniejszych kwadratów. Ogólny wzór modelu ma postać (1):

liczba_wypożyczeńn ${ }_{i t}=\alpha_{i}+\beta_{1}{ }_{1}^{*}$ Liczba_czytelników ${ }_{i t}$ $+\beta_{2}{ }^{*}{ }^{*}$ Liczba_woluminó $\mathrm{w}_{i t}+\beta_{3}{ }^{*}$ Wartość_dotacji ${ }_{i t}+\varepsilon$

Objaśnienie zmiennych:

1. Zmienna objaśniana:

Liczba_wypożyczeń ${ }_{\mathrm{it}}$ - liczba wypożyczeń woluminów w $i$ bibliotece w $t$ roku

2. Zmienne objaśniające:

Liczba_czytelników ${ }_{\text {it }}$ - liczba zarejestrowanych czytelników w $i$ bibliotece w $t$ roku

Liczba_woluminów $\mathrm{w}_{\mathrm{it}}$ - wielkość księgozbioru w $i$ bibliotece $\mathrm{w} t$ roku

Wartość_dotacji ${ }_{\mathrm{it}}$ - wartość uzyskanej dotacji w $i$ bibliotece $\mathrm{w} t$ roku

gdzie $i$ - oznacza bibliotekę poddaną badaniu, a $t$ - oznacza rok badania

W badaniu posłużono się także jakościowymi metodami badawczymi, najbliższymi etnografii organizacyjnej [Kostera 2003]. Metody jakościowe pozwalają nie 
tylko skrupulatnie opisać badany problem i grupę społeczną, której dotyczy, ale także jak najbardziej zrozumieć perspektywę uczestników dzięki „zanurzeniu” w teren badawczy [Krzyworzeka 2008; 2015].

Zostało przeprowadzonych pięć indywidualnych wywiadów pogłębionych z pracownikami bibliotek, głównie ze szczebli zarządczych, obserwacje oraz analiza stron internetowych wybranych placówek. Badania odbyły się pomiędzy 3 a 16 lipca 2018 roku. Wywiady wykonano bezpośrednio albo przez telefon. Pytania dotyczyły m.in. tego, czym jest dzisiejsza biblioteka, kim jest czytelnik oraz jaka będzie przyszłość bibliotek.

\section{Wyniki badań ilościowych i jakościowych}

Przyjmując liczbę wypożyczeń za miernik czytelnictwa, we wszystkich bibliotekach w okresie 1999-2016 wskaźnik ten zmniejszył się wyraźnie, szczególnie po 2006 roku (wykres 1). W przypadku Nowohuckiej i Śródmiejskiej BP największą liczbę wypożyczeń zanotowano w 2004 roku i była ona o ponad 30\% wyższa niż w 1999 roku. Dla bibliotek Podgórskiej i Krowoderskiej największą liczbę wypożyczeń zaobserwowano w 2006 roku i były one o 23\% wyższe niż w 1999 roku. Po tym okresie liczba wypożyczeń systematycznie spada. Szczególnie wyraźnie było to widoczne w Śródmiejskiej BP, gdzie liczba ta zmniejszyła się o 67\% w ciągu dekady, między 2006 a 2016 rokiem.

Te niekorzystne zmiany czytelnictwa następowały mimo rosnącej lub stabilnej liczby czytelników, co przedstawia wykres 2. W trzech bibliotekach liczba czytelników w tym okresie wzrosła od 31\% w Śródmiejskiej BP do ponad 50\% w Krowoderskiej BP. Tylko w Nowohuckiej BP liczba czytelników została na zbliżonym poziomie przez cały okres. Należy podkreślić, iż do 2003-2004 we wszystkich omawianych bibliotekach liczba czytelników rosła, osiągając poziom o około $25 \%$ wyższy w porównaniu do 1999 roku.

Po kolejnych pięciu latach we wszystkich bibliotekach liczba czytelników zmniejszyła się, osiągając swoje minimum, zbliżone do poziomu z 1999 roku.

Jeśli chodzi o wielkość księgozbioru (wykres 3), w dwóch bibliotekach liczba woluminów zmniejszyła się z poziomu 300 tys. do 230 tys., czyli o około jedną czwartą. Są to Śródmiejska i Krowoderska BP. W Nowohuckiej BP liczba ta pozostała na zbliżonym poziomie, zaś w Podgórskiej BP wzrosła o około 17\% w ciągu 17 lat.

Wartość dotacji we wszystkich bibliotekach rosła przez cały okres badawczy, średnio o 4-6\% w skali roku (wykres 4). Najsilniejszy wzrost zanotowano na początku XXI wieku, co było spowodowane zmianą sposobu finansowania bibliotek w Polsce - z budżetu centralnego na budżety samorządowe. W całym okresie w Podgórskiej BP i Krowoderskiej BP wartość dotacji wzrosła ponad dziewięciokrotnie, zaś w Nowohuckiej BP - niemal 7 razy, a w Śródmiejskiej PB - ponad 8,5 raza. 


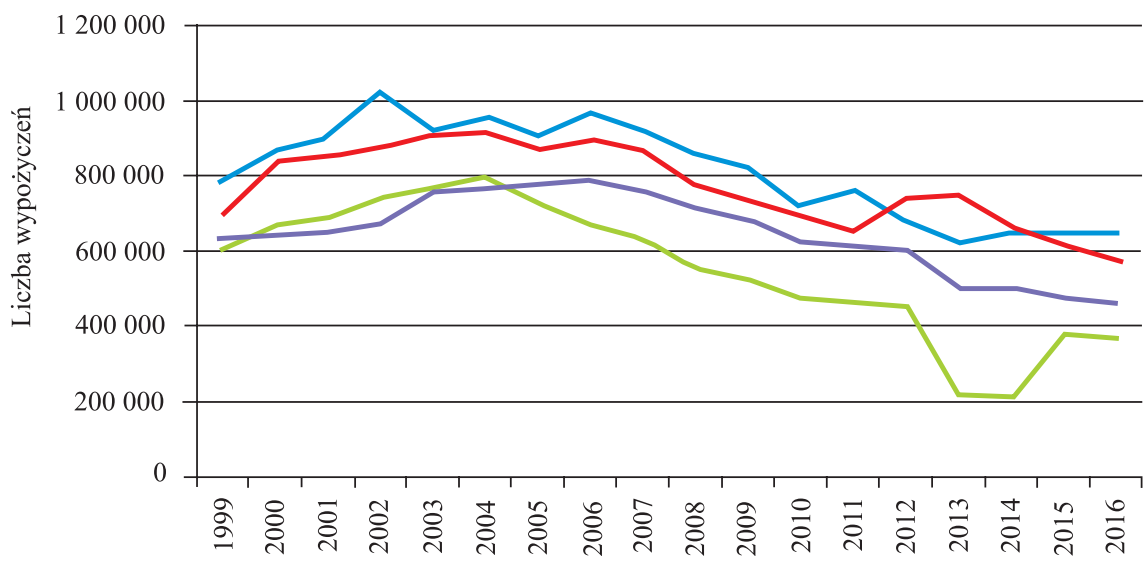

— Podgórska BP Nowohucka BP Śródmiejska BP Krowoderska BP

Wykres 1. Liczba wypożyczeń

Źródło: opracowanie własne na podstawie Raportów o Stanie Miasta Kraków za lata 1999-2016

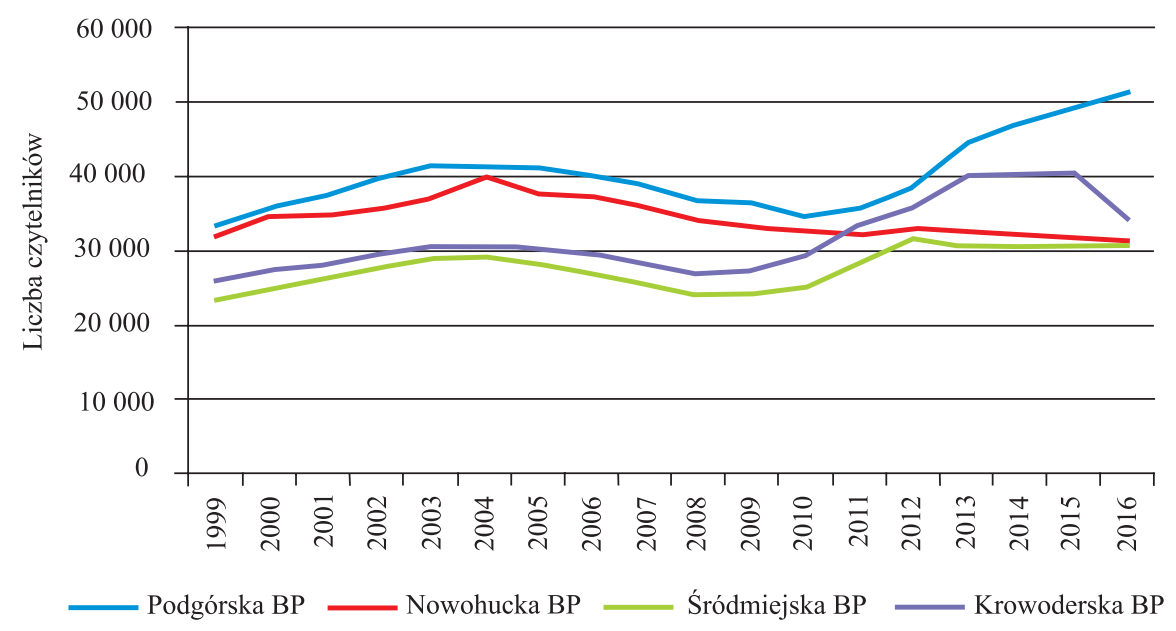

Wykres 2. Liczba czytelników

Źródło: opracowanie własne na podstawie Raportów o Stanie Miasta Kraków za lata 1999-2016 


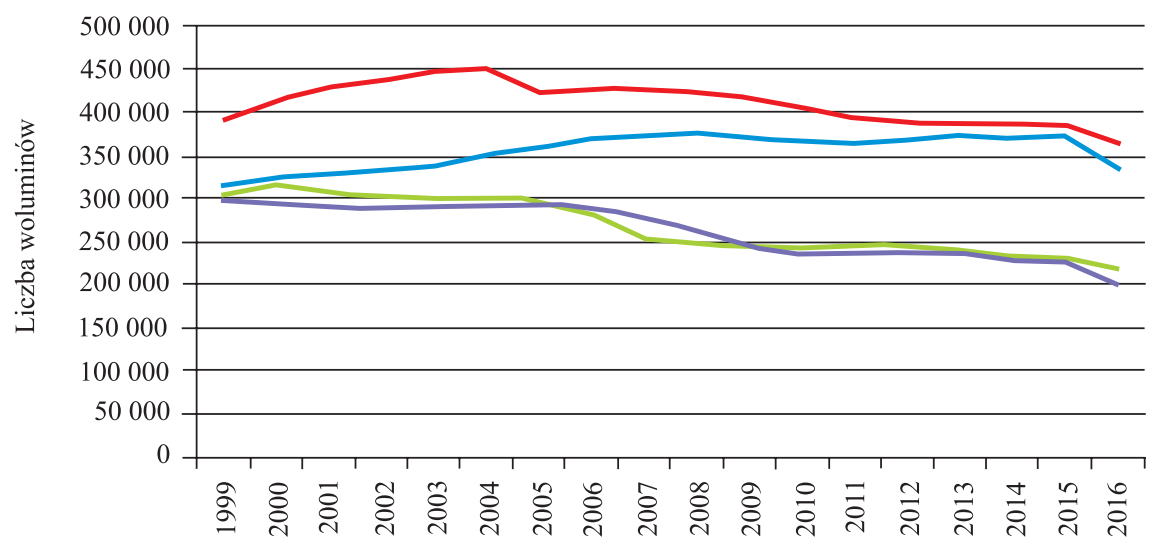

Podgórska BP Śródmiejska BP

Krowoderska BP

Wykres 3. Liczba woluminów

Źródło: opracowanie własne na podstawie Raportów o Stanie Miasta Kraków za lata 1999-2016

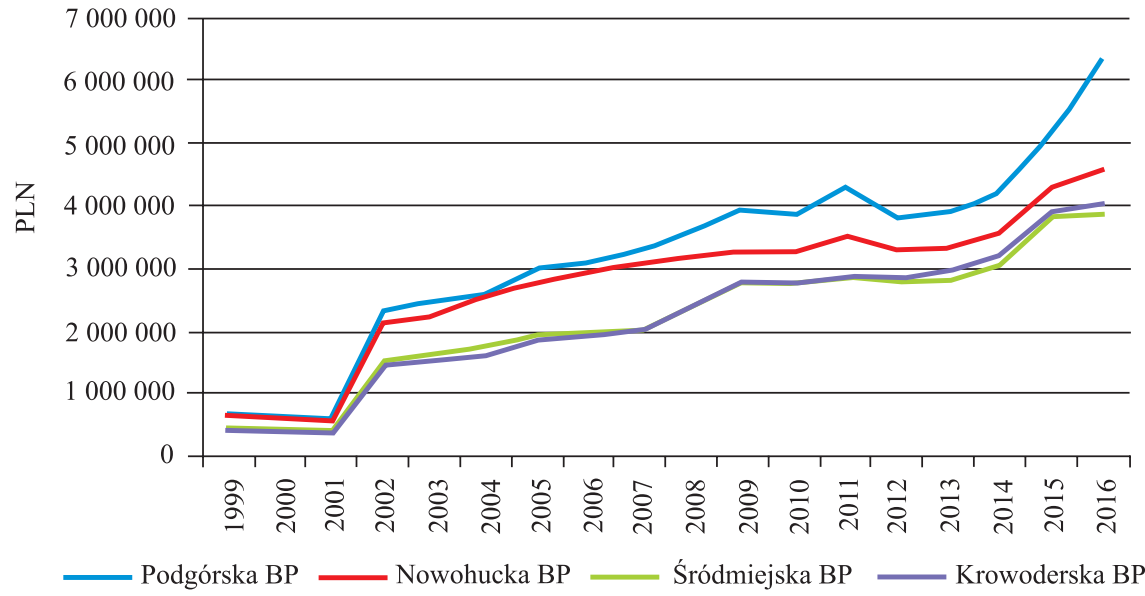

Wykres 4. Wysokość dotacji

Źródło: opracowanie własne na podstawie Raportów o Stanie Miasta Kraków za lata 1999-2016

Na podstawie tej wstępnej analizy można wysnuć niepokojące wnioski, iż zmniejszającej się liczbie wypożyczeń towarzyszy rosnąca wartość dotacji, przy liczbie zarejestrowanych czytelników na poziomie zbliżonym do tego z 1999 roku. Może to świadczyć o nieskuteczności wydatkowania środków publicznych, jeśli cel działalności bibliotek zostanie ograniczony do wzrostu czytelnictwa. 


\section{Analiza wskaźnikowa}

Na podstawie dostępnych danych, dotyczących liczby czytelników, liczby woluminów, liczby wypożyczeń oraz wartości dotacji w każdej z bibliotek w okresie 1999-2016, stworzono wskaźniki opisujące zachodzące zmiany. Są to: wielkość dotacji na jednego czytelnika w zł, liczba zrealizowanych wypożyczeń jednego czytelnika, liczba wypożyczeń jednego woluminu oraz liczba woluminów przypadająca na jednego czytelnika, co prezentują wykresy $5-8$. Ich wspólna analiza może być traktowana jako ocena skuteczności działania bibliotek.

Niestety, wnioski nie są zbyt optymistyczne. W każdej z omawianych bibliotek rok 1999 był najkorzystniejszy pod względem liczby wypożyczeń w stosunku do wielkości dotacji. Przy najniższej dotacji finansującej działalność bibliotek uzyskiwano najwyższy wskaźnik czytelnictwa, liczony liczbą wypożyczeń zrealizowanych przez jednego czytelnika. Wskaźnik osiągnął wówczas poziom od około 30 razy w PB Śródmiejskiej do 24 razy w pozostałych bibliotekach. Oznacza to, że statystyczny czytelnik w tamtym czasie odwiedzał bibliotekę co najmniej 2 razy miesięcznie. W kolejnych latach wskaźnik ten zmniejszał się, by w 2016 roku w BP Krowoderskiej i Podgórskiej osiągnąć poziom 12, co oznacza, że w ciągu 17 lat liczba wypożyczeń dokonywanych przez czytelników zmniejszyła się o połowę.

W 1999 r. w trzech bibliotekach: Krowoderskiej, Nowohuckiej i Śródmiejskiej liczba woluminów przypadająca na jednego czytelnika była także najwyższa w porównaniu do późniejszych lat i wyniosła minimum 12 sztuk. W kolejnych latach wskaźnik ten zmniejszał się od 33\% w BP Nowohuckiej do nawet 67\% w BP Krowoderskiej. Trzeba zaznaczyć, że w BP Podgórskiej w okresie 1999-2008 liczba woluminów na jednego czytelnika wzrosła z 9 do 12, by potem zmniejszyć się do poziomu 6 .

W BP Nowohuckiej i Podgórskiej w 1999 roku liczba wypożyczeń jednego woluminu była najwyższa i wyniosła odpowiednio niemal 2 dla BP Nowohuckiej i niemal 3 - dla BP Podgórskiej. W okresie 1999-2009 BP Śródmiejska i BP Krowoderska zanotowały wzrost tego wskaźnika z poziomu 2 do 3 , by następnie do 2016 roku zanotować podobny jak w innych omawianych bibliotekach spadek, o 1 wypożyczenie w skali roku.

Wszystkie te niekorzystne zmiany następowały równolegle do zwiększającej się wielkości dotacji udostępnianych bibliotekom, z poziomu około $20 \mathrm{zł} \mathrm{w}$ przeliczeniu na jednego czytelnika do poziomu ponad 130 zł. Może to oznaczać nieefektywność kosztową bibliotek. Wykorzystując znacznie większe wsparcie finansowe z tytułu otrzymywanej dotacji, w 2016 roku osiągnięto znacznie niższy poziom czytelnictwa niż w 1999 roku. Mimo istotnie zwiększonej dotacji na finansowanie bibliotek, w każdej z czterech omawianych bibliotek nie osiągnięto celów, jakie są stawiane bibliotekom publicznym we wspomnianej ustawie o bibliotekach, tj. zwiększania czytelnictwa wśród obywateli. Szczegółowa analiza ekonometryczna potwierdziła zanotowane obserwacje. 


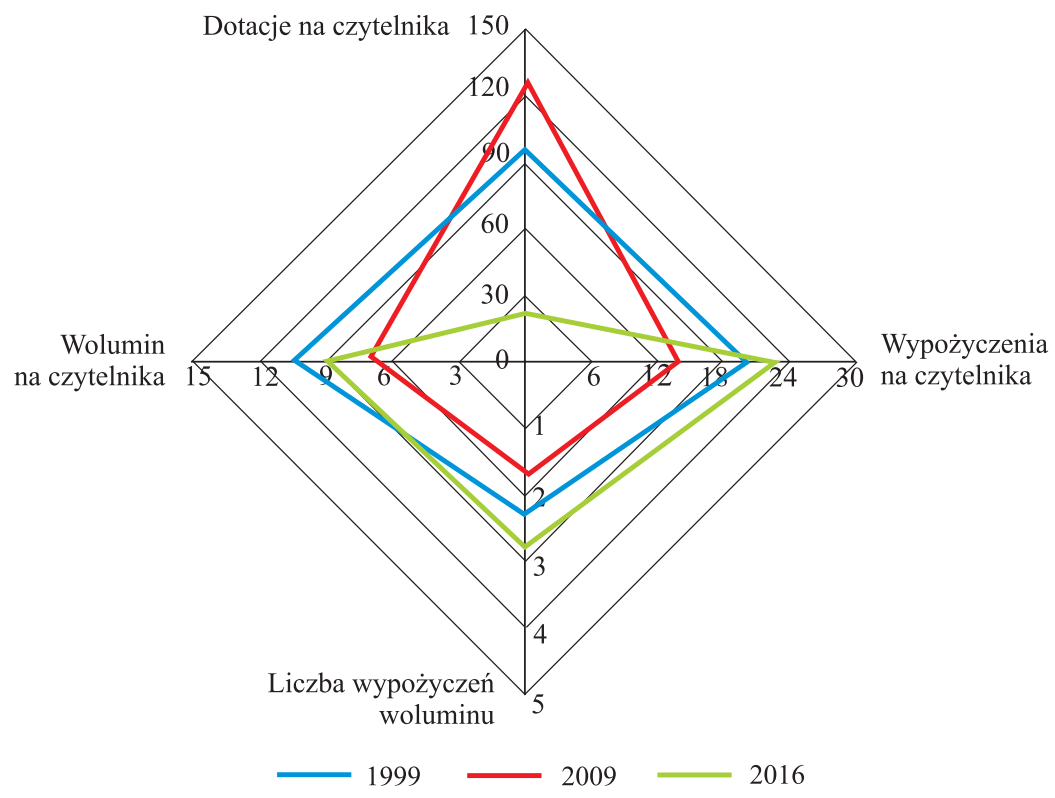

Wykres 5. Podgórska BP

Źródło: opracowanie własne na podstawie Raportów o Stanie Miasta Kraków za lata 1999-2016

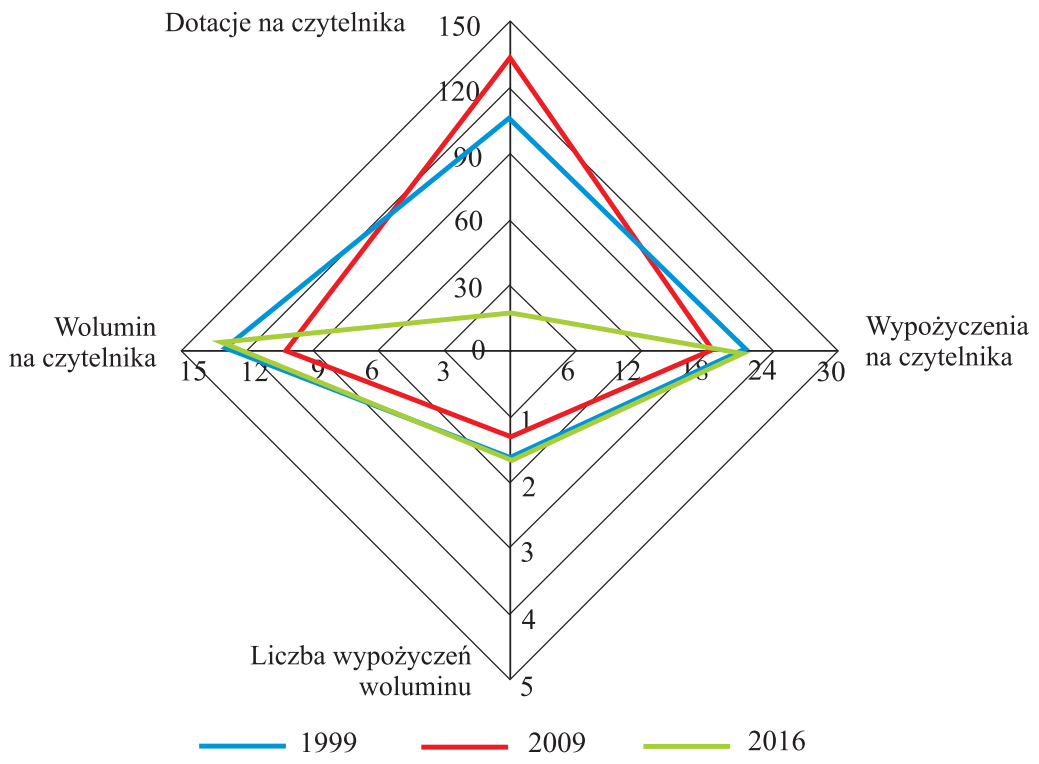

Wykres 6. Nowohucka BP

Źródło: opracowanie własne na podstawie Raportów o Stanie Miasta Kraków za lata 1999-2016 


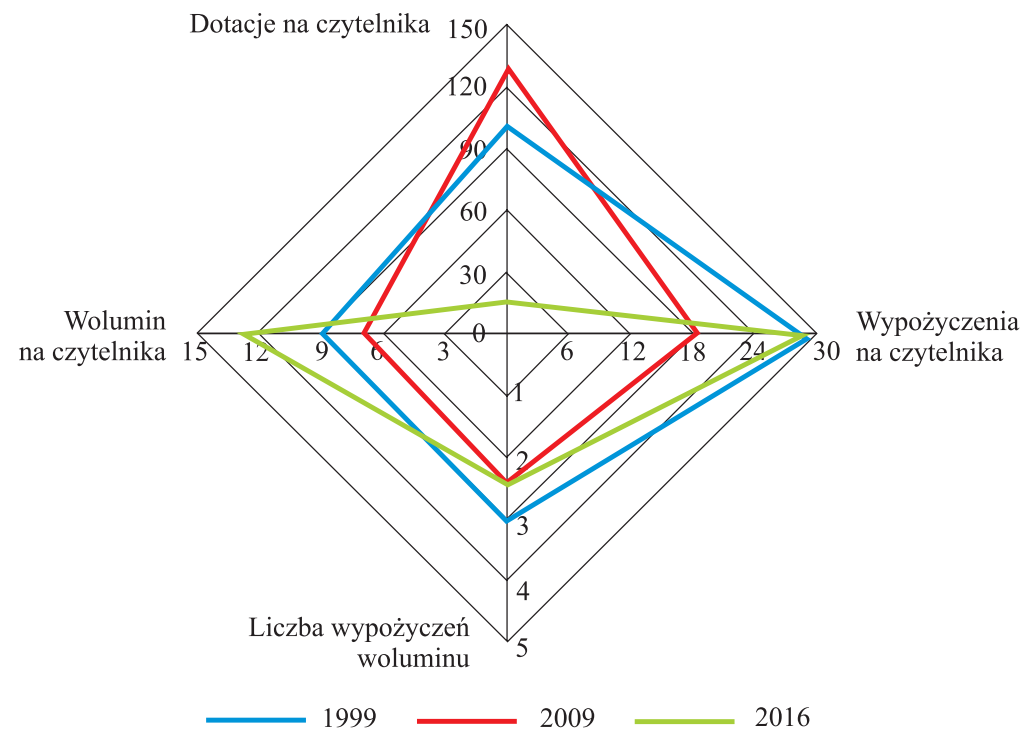

\section{Wykres 7. Śródmiejska BP}

Źródło: opracowanie własne na podstawie Raportów o Stanie Miasta Kraków za lata 1999-2016

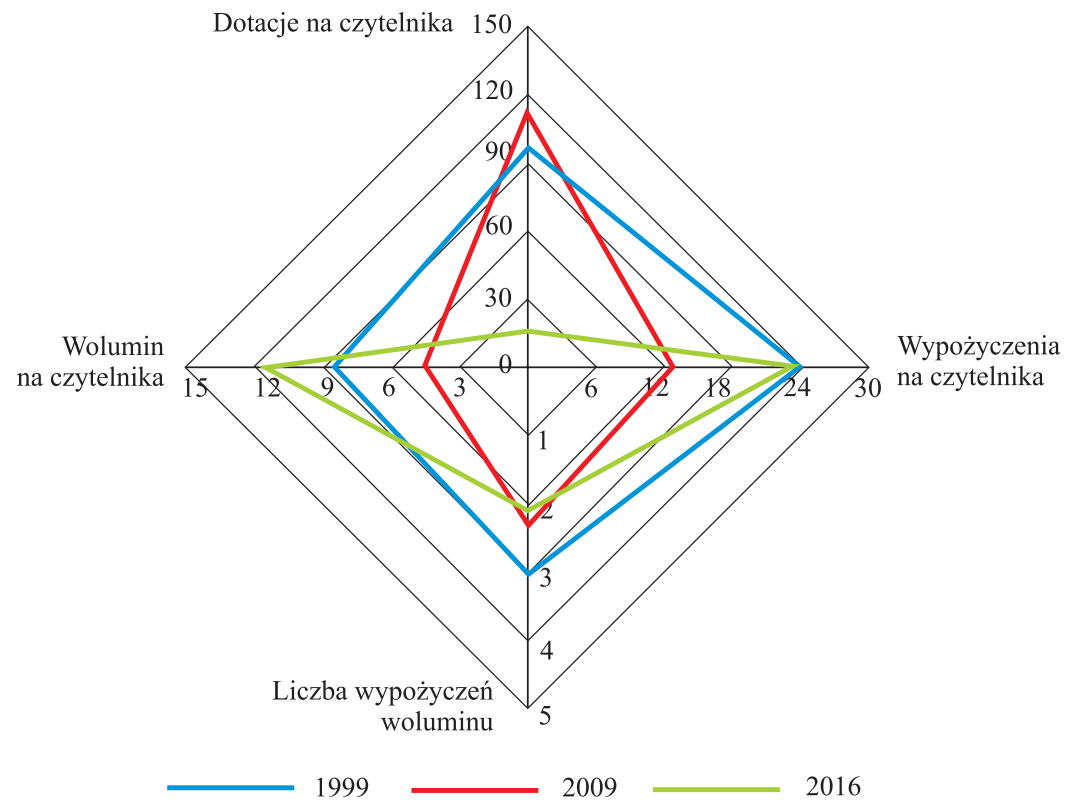

\section{Wykres 8. Krowoderska BP}

Źródło: opracowanie własne na podstawie Raportów o Stanie Miasta Kraków za lata 1999-2016 
Przyjmując za miernik poziomu czytelnictwa liczbę wypożyczonych woluminów, można określić wpływ wybranych czynników na jego poziom. Wśród wybranych determinant jest wielkość księgozbioru liczona liczbą woluminów, liczba czytelników, liczba wypożyczeń oraz wielkość uzyskiwanej dotacji. W celu weryfikacji zauważonych zmian przeprowadzono badanie korelacji pomiędzy poszczególnymi zmiennymi. Sprawdzona została więc hipoteza o występowaniu zależności pomiędzy poziomem czytelnictwa a wielkością dotacji, liczbą woluminów i liczbą czytelników. Dla doboru odpowiednich testów statystycznych sprawdzono, czy rozkłady tych zmiennych w kolejnych latach od 1999 do 2016 roku nie odbiegają istotnie od rozkładu normalnego. Wyniki zaprezentowano w tabeli 3.

Tabela 3. Wyniki testu Kołmogorowa-Smirnowa dla badanych zmiennych

\begin{tabular}{|l|c|c|c|c|}
\cline { 2 - 5 } \multicolumn{1}{c|}{} & $\begin{array}{c}\text { liczba } \\
\text { wypożyczeń }\end{array}$ & $\begin{array}{c}\text { liczba } \\
\text { czytelników }\end{array}$ & $\begin{array}{c}\text { liczba } \\
\text { woluminów }\end{array}$ & $\begin{array}{c}\text { wartość } \\
\text { dotacji }\end{array}$ \\
\hline $\begin{array}{l}\text { KS na normalność } \\
\text { rozkładu }\end{array}$ & 0,095 & 0,073 & 0,11 & 0,105 \\
\hline p testu KS & 0,508 & 0,805 & 0,328 & 0,375 \\
\hline
\end{tabular}

Źródło: opracowanie własne.

Przeprowadzony test statystyczny Kołmogorowa-Smirnowa nie wykazał dla jakiejkolwiek zmiennej, żeby rozkłady wskaźników istotnie odbiegały od rozkładu normalnego. Co więcej, w oparciu o wykres rozrzutu zmiennych przyjęto liniową postać zależności między poszczególnymi zmiennymi. W związku z tym dla zbadania zależności pomiędzy tymi zmiennymi został wyznaczony współczynnik korelacji $r$-Pearsona i została wyznaczona jego istotność odpowiednimi testami parametrycznymi (tabela 4 ).

Tabela 4. Wskaźniki korelacji

\begin{tabular}{|l|c|c|c|c|c|c|c|c|}
\cline { 2 - 9 } \multicolumn{1}{c|}{} & \multicolumn{2}{c|}{$\begin{array}{c}\text { liczba } \\
\text { wypożyczeń }\end{array}$} & \multicolumn{2}{c|}{$\begin{array}{c}\text { liczba } \\
\text { czytelników }\end{array}$} & \multicolumn{2}{c|}{$\begin{array}{c}\text { liczba } \\
\text { woluminów }\end{array}$} & \multicolumn{2}{c|}{$\begin{array}{c}\text { wartość } \\
\text { dotacji }\end{array}$} \\
\cline { 2 - 9 } \multicolumn{1}{c|}{} & $\mathbf{r}$ & $\mathbf{p}$ & $\mathbf{r}$ & $\mathbf{p}$ & $\mathbf{r}$ & $\mathbf{p}$ & $\mathbf{r}$ & $\mathbf{p}$ \\
\hline $\begin{array}{l}\text { liczba } \\
\text { wypożyczeń }\end{array}$ & & & 0,303147 & 0,01 & 0,669486 & $<0,001$ & $-0,25958$ & 0,028 \\
\hline $\begin{array}{l}\text { liczba } \\
\text { czytelników }\end{array}$ & 0,303147 & 0,01 & & & 0,412544 & $<0,001$ & 0,515336 & $<0,001$ \\
\hline
\end{tabular}




\begin{tabular}{|l|c|c|c|c|c|c|c|c|}
\hline $\begin{array}{l}\text { liczba } \\
\text { woluminów }\end{array}$ & 0,669486 & $<0,001$ & 0,412544 & $<0,001$ & & & 0,052869 & 0,659 \\
\hline $\begin{array}{l}\text { wartość } \\
\text { dotacji }\end{array}$ & $-0,25958$ & 0,028 & 0,515336 & $<0,001$ & 0,052869 & 0,659 & & \\
\hline
\end{tabular}

Źródło: opracowanie własne.

W oparciu o wyniki postawionych hipotez badawczych mówiących o zależności pomiędzy zmiennymi można stwierdzić, że korelacja pomiędzy niemal wszystkimi zmiennymi jest dodatnia i jest istotna statystycznie na poziomie 0,05 . Tylko zależność pomiędzy wartością dotacji a liczbą woluminów nie jest istotna statystycznie na poziomie 0,05 . Ponadto, na podstawie przeprowadzonych testów można powiedzieć, że wartość dotacji i liczba wypożyczeń są ujemnie współzależne, co oznacza, że wzrostowi wartości dotacji nie towarzyszy wzrost liczby wypożyczeń, co może świadczyć o nieskuteczności wydawania pieniędzy publicznych na rozwój czytelnictwa.

Dla pogłębienia badań sprawdzono, które zmienne mają największy wpływ na wielkość czytelnictwa. Badanie przeprowadzono dla dwóch modeli, gdzie Model 1 oznacza estymację panelową metodą najmniejszych kwadratów, zaś Model 2 estymację ze stałymi efektami, z wykorzystaniem w obu przypadkach 72 obserwacji. Dodatkowo przygotowano Model 3 uwzględniający tylko zmienne istotne na poziomie 0,05 . Wyniki przedstawia tabela 5 .

W przypadku Modelu 1 wszystkie zmienne są istotne statystycznie, z tym że model tłumaczy jedynie 58,65\% zmiany poziomu czytelnictwa wybranymi zmiennymi objaśniającymi. Oznacza to, że ponad $40 \%$ zmienności czytelnictwa powinno być wyjaśnione przez inne czynniki.

W przypadku Modelu 2 wskaźnik determinacji jest wyższy i wyniósł ponad 70\%, jednak poziomu czytelnictwa nie można wyjaśniać liczbą czytelników, a jedynie wartością dotacji i wielkością księgozbioru. Trzeba podkreślić ujemną zależność czytelnictwa od wartości dotacji. Środki finansowe w ramach dotacji są wydawane na różne wydarzenia angażujące społeczeństwo. Jednak mimo iż rośnie liczba zapisujących się do bibliotek, nie są oni aktywnymi czytelnikami wypożyczającymi książki. Jedynie wielkość księgozbioru jest istotna statystycznie i pozytywnie wpływa na wielkość czytelnictwa. Oznacza to, że większy księgozbiór przyczyni się do wzrostu czytelnictwa, a więc dotacja powinna być wydatkowana na zakupy nowych pozycji do bibliotek, by te mogły zrealizować swój cel statutowy, jakim jest zwiększanie czytelnictwa. Jednak zważywszy na brak istotności korelacji pomiędzy liczbą woluminów w bibliotekach a wielkością dotacji, można powiedzieć, że dotacje są wykorzystywane na inne działania niż zwiększanie księgozbioru, które niestety nie przynoszą oczekiwanego skutku, jakim jest wzrost czytelnictwa. 


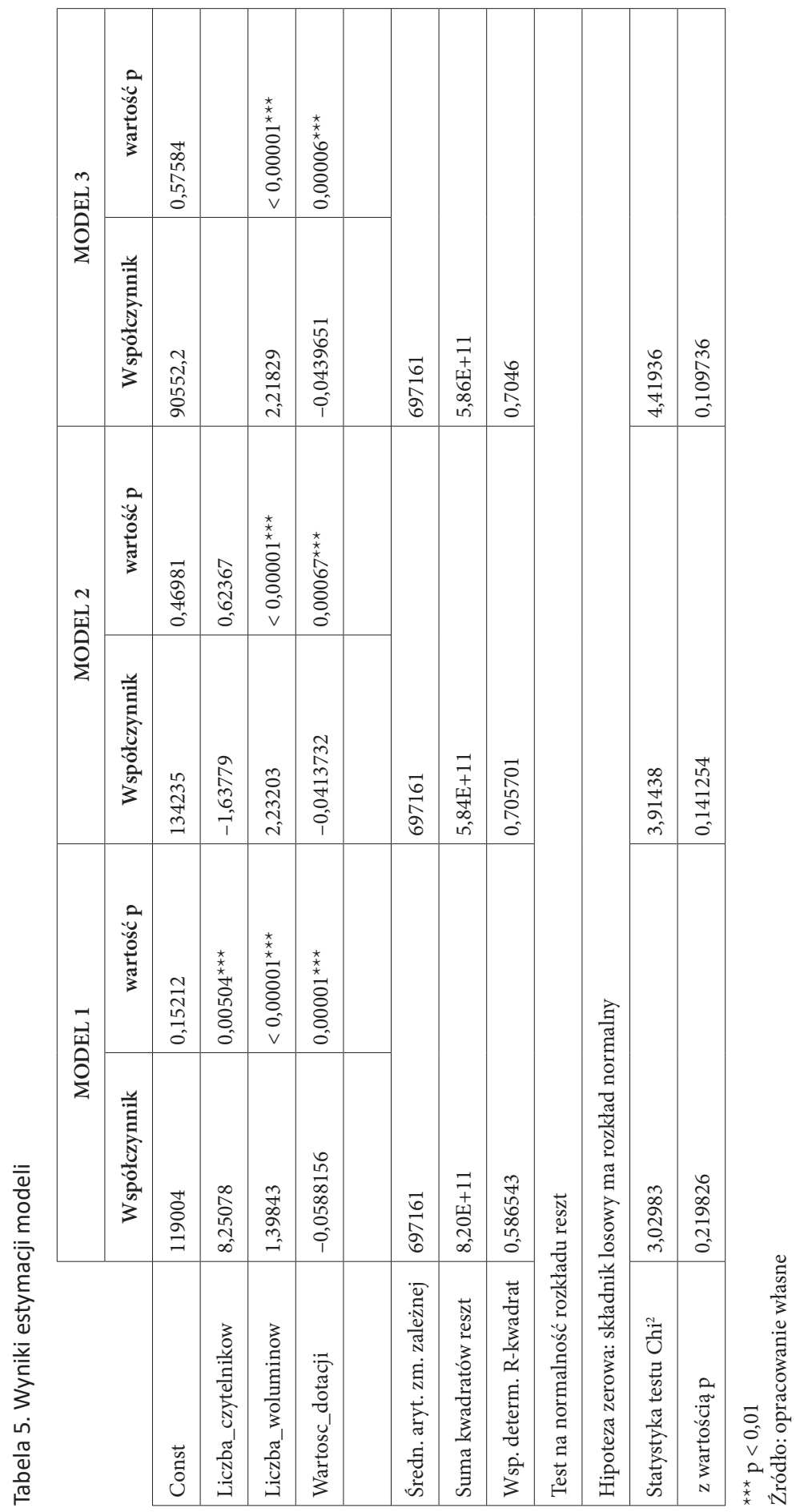




\section{Wyniki badań jakościowych}

Z przeprowadzonych wywiadów z osobami zarządzającymi bibliotekami oraz z obserwacji funkcjonowania bibliotek wynika, że przez ostatnie kilkanaście lat zasadniczo zmieniła się rola biblioteki. Już nie jest tylko wypożyczalnią, z zamkniętą przed czytelnikiem strefą książek. Co jest znamienne, większość badanych pracowników mówiła „użytkownik” biblioteki, a nie „czytelnik”. Jak zauważyła jedna z rozmówczyń: „biblioteka stała się miejscem”. Biblioteka jest miejscem przede wszystkim otwartym, w którym czytelnicy w różnym wieku, z różnymi potrzebami mogą przebywać i swobodnie się poruszać. W dalszym ciągu służy wypożyczaniu i czytaniu książek, a także stwarza spokojną przestrzeń do nauki. Biblioteki przyciągają użytkowników oczywiście jakością księgozbioru. Czytelnicy oczekują przede wszystkim, że będzie pełen nowości. To, co pojawia się w księgarniach, powinno natychmiast znaleźć się w bibliotece. I faktycznie, badane biblioteki poczyniły wiele starań, żeby nowa, interesująca książka znalazła się w nich możliwie szybko - w ciągu tygodnia, dwóch od premiery.

Biblioteka stała się również miejscem o wielu innych obliczach. Przede wszystkim realizowane są w niej różnorodne usługi - zaczynając od wypożyczania e-booków, poprzez umożliwienie skorzystania z komputera z Internetem (bądź samego Internetu bezprzewodowego), używania drukarki 3D, aż do udzielania informacji, pomocy w szukaniu informacji, wsparcia w pisaniu własnego CV. Dzisiejsza biblioteka jest również miejscem aktywnego i ciekawego spędzania czasu - wypicia kawy, spotkania się ze znajomymi, uczestniczenia w przedstawieniach teatralnych dla dzieci, grania w planszówki lub na PlayStation, spotkania z interesującymi ludźmi (nie tylko pisarzami), udziału w klubach dyskusyjnych, warsztatach fotograficznych, kursach komputerowych.

Niektóre biblioteki znajdują się w budynkach dworców kolejowych, w centrach handlowych. Inne powstają w mniej znanych dzielnicach dużych miast, gdzie pełnią także funkcje lokalnych centrów kultury, spotkań sąsiedzkich, centrów informacji i nauki. Czasami mieszkańcy danej dzielnicy sami starają się u władz o powstanie biblioteki.

Z bibliotek korzystają właściwie ludzie w każdym wieku. Również małe dzieci, które przychodzą z rodzicami na różnego rodzaju wydarzenia, spotkania przygotowane specjalnie dla nich, a potem często wypożyczają książki na karty rodziców. Niedługo w wielu bibliotekach będą one mogły mieć swoje własne karty i być pełnoprawnymi czytelnikami. Niekiedy biblioteki przygotowują różnego rodzaju gry i zabawy, w których zdobywa się punkty za wypożyczone (i przeczytane) książki. Mały czytelnik uczy się w ten sposób m.in. konsekwencji, ale także rozumienia idei miejsca, jakim jest biblioteka.

Jaka będzie przyszłość bibliotek za 5, 10 lat? Wszyscy rozmówcy byli w tej kwestii zgodni - na pewno biblioteki nie znikną. Już obecnie biblioteki publiczne starają się 
badać potrzeby i oczekiwania swoich użytkowników i dostosowywać do nich swoją ofertę. Jak powiedziała jedna z rozmówczyń: „Użytkownik jest najważniejszy. Bez niego będziemy tylko magazynem książek”. Ponieważ pracownicy bibliotek zauważyli jakiś czas temu, że ich instytucja w oczach użytkowników to nie tylko książki, starają się aktywnie reagować na wyzwania współczesnego świata. Zatem - modernizują wnętrza, aktualizują zbiory, wykorzystują nowoczesne technologie, coraz bardziej rozszerzają wachlarz usług, ale także rozmawiają z użytkownikami i budują z nimi długotrwałe relacje. Wydaje się to zgodne $\mathrm{z}$ realizacją koncepcji cyfrowych tubylców i imigrantów (por. tabele 1 i 2), w przypadku której różnego rodzaju potrzeby różniących się bardzo od siebie czytelników zostają realizowane przez zmieniające się, podążające za użytkownikami instytucje kultury.

\section{Dyskusja}

Niewątpliwie wszelkie próby przewidzenia przyszłości są bardzo trudnym zadaniem. Szczególnie skomplikowane wydaje się to w dobie tak dynamicznych zmian życia społecznego, które po pierwsze głęboko wpływają na funkcjonowanie wszelkich instytucji społecznych, a po drugie szybko zdezaktualizowują istniejące narzędzia badawcze. W świetle rozważań o zmieniającej się roli bibliotek, chociażby w odniesieniu do realizacji potrzeb cyfrowych imigrantów i tubylców (por. przegląd literatury), oraz o kierunkach ich rozwoju w przyszłości, otwarte pozostaje pytanie o to, jakimi metodami oceniać działanie bibliotek, ich efektywność i skuteczność. O ile proste wskaźniki, jak również klasyczne ekonometryczne metody ilościowe nie oddają złożonej natury funkcjonowania biblioteki w społeczeństwie, o tyle wskazane jest poszukać innych metod do oceny jej działania. Niewątpliwie biblioteki i efekty ich działalności z ekonomicznego punktu widzenia należą do dóbr trudno mierzalnych. Wprawdzie wartość nakładów na powstanie i działanie biblioteki nie jest problematyczna do ustalenia, ale efekty i skutki jej funkcjonowania, szczególnie w dobie zmieniającej się jej roli, nie są łatwym zadaniem do skwantyfikowania. Niezbędne jest więc znalezienie takich metod, które pozwolą na wycenę tego, co nie jest jednoznacznie wyceniane, np. rola biblioteki w społeczeństwie. Jedną z takich metod może być koncepcja całkowitej wartości ekonomicznej [Willis 2014: 145-181], czyli pieniężny miernik wyrażający zmiany dobrobytu jednostki w wyniku określonych działań czy procesów, np. w konsekwencji możliwości korzystania $\mathrm{z}$ biblioteki. Teoria ta jest wykorzystywana do określenia wartości dóbr, dla których nie istnieje standardowy rynek lub cena rynkowa nie odzwierciedla całkowitej wartości zasobów, które są zwykle niepowtarzalne. W takim przypadku całkowita wartość ekonomiczna dzieli się na wartość użytkową i nieużytkową. W ramach wartości użytkowej wyróżnia się wartości wynikające z bezpośredniego i pośredniego użytkowania. W przypadku bibliotek wartość bezpośrednia winna być ustalana na 
podstawie cen rynkowych zasobów, a w jej ramach można także wskazać na konsumpcyjne i niekonsumpcyjne wartości użytkowe, w zależności od tego, czy wykorzystanie zasobu powoduje ograniczenie dostępu lub jego brak dla innych osób. Wartość wynikająca z pośredniego użytkowania oznacza wartość innych korzyści wynikających z istnienia bibliotek w społeczeństwie, co jest o wiele trudniejsze do wyceny. Elementami wartości nieużytkowej są: wartość opcjonalna - odnosząca się do korzyści uzyskiwanych w przyszłości, a więc wiąże się z odroczonym w czasie użytkowaniem zasobu biblioteki; wartość dziedziczona - czyli wartość walorów, którą obecni użytkownicy pragną zachować dla przyszłych pokoleń, a także wartość egzystencjalna - istnienia, związana z samym faktem istnienia danego obiektu. $\mathrm{Na}$ rysunku 1 przedstawiono propozycję autorskiej koncepcji oceny funkcjonowania bibliotek, inspirowaną dwoma teoriami (i narzędziami): teorią całkowitej wartości ekonomicznej [Freeman 1993] oraz klasyfikacji zasobów niematerialnych Sveiby’ego [Król 2007]. Poszczególne elementy całkowitej wartości zostały pokazane w odniesieniu do działania bibliotek, wraz z informacją o malejącej wymierności poszczególnych elementów, co oznacza rosnące problemy z ich kwantyfikacją.

Określenie poszczególnych wartości pozwoli na oszacowanie wartości bibliotek i ich wpływu na otoczenie ekonomiczno-społeczne. W tym celu będą potrzebne różne metody i techniki badawcze. Literatura przedmiotu wykorzystuje metodę analizy kosztów w stosunku do korzyści (ang. CBA - cost-benefit analysis), metodę analizy warunkowej (ang. CVM - contigent valuation method), określanie wartości dodanej dla użytkownika (ang. consumer surplus method) i metodologię oceny stopy wzrostu z inwestycji (ang. ROI - return of investment) [Głowacka 2011: 217-230; Missingham 2005: 143; Derfert-Wolf 2016]. Kapitał intelektualny organizacji również można mierzyć na wiele sposobów [por. np. Edvinsson, Malone 2001; Stewart 2001; Dobija 2003], jednak zdecydowana większość metod odnosi się do badania organizacji biznesowych, czyli przynoszących zyski finansowe. W przypadku biblioteki, której cele istnienia są inne (por. podrozdział 1), ocena jej działania i narzędzia do tego użyte powinny być interdyscyplinarne. Takie podejście do oceny bibliotek pozwoli, z jednej strony, na określenie efektywności i skuteczności jej działania, z drugiej natomiast pozwoli wziąć pod uwagę zmieniającą się rolę i wzrastające znaczenie budowanych w niej i wokół niej relacji społecznych. 


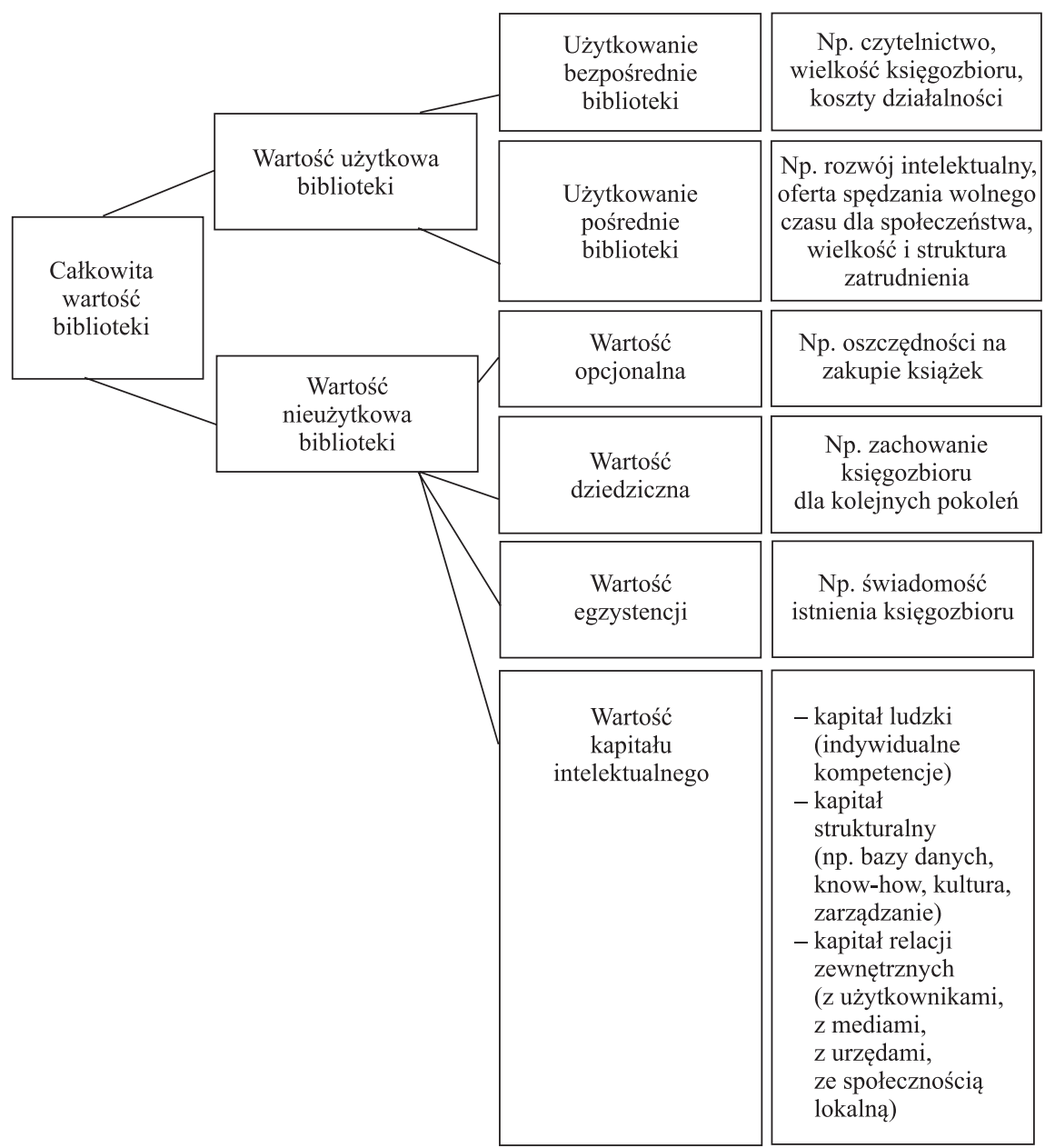

Rysunek 1. Całkowita wartość a ocena działania biblioteki

Źródło: opracowanie własne na podstawie: Freeman [1993], Król [2007].

\section{Zakonczenie}

Przeprowadzone badania odzwierciedlają i uwzględniają zmieniającą się rolę bibliotek w społeczeństwie. Dzisiejsze biblioteki nie są już miejscami, gdzie panuje cisza, ale tętnią życiem, oferując zróżnicowane usługi dla zróżnicowanego odbiorcy, pełniąc często poważną rolę kulturotwórczą. Ich użytkownikiem nie jest już tylko czytelnik, czyli osoba poszukująca książki w papierowym woluminie, ale także chcąca ciekawie i aktywnie spędzić wolny czas, potrzebująca pomocy lub zainteresowana 
spotkaniem z innymi osobami. Wydaje się, że wszelkie funkcje społeczne i kulturowe będą się w sposobie funkcjonowania bibliotek mnożyć. W konsekwencji musi się też zmienić podejście do oceny biblioteki. Wykorzystywanie klasycznych metod badawczych, stosowanych głównie w ocenie skuteczności działania instytucji komercyjnych, może nadmiernie upraszczać złożoność funkcjonowania instytucji kultury (tj. biblioteki), a tym samym prowadzić do błędnych wniosków o nieefektywności i nieskuteczności podejmowanych przez nią działań, jak to zaprezentowano na przykładzie bibliotek w Krakowie. Zróżnicowane zadania biblioteki wymagają podjęcia niestandardowych metod ich oceny, np. zaproponowaną autorską metodę, uwzględniającą pojawiające się coraz silniejsze relacje społeczne na styku biblioteka - zewnętrzny świat społeczny. Jej zastosowanie pozwoli na skwantyfikowanie wszelkich działalności bibliotek (możliwych do skwantyfikowania) oraz określenie ich wpływu na otoczenie społeczno-ekonomiczne.

\section{Bibliografia}

Biliński L. (2002), Wskaźniki funkcjonalności bibliotek (Na marginesie projektu normy ISO 11620), „Bibliotekarz”, nr 10, 6-9.

Budyńska B., Jezierska M. (2011), Polityka biblioteczna i finansowanie bibliotek publicznych w Polsce, „Biuletyn EBIB”, nr 8 (126).

Derfert-Wolf L. (2016), Badanie funkcjonalności i wplywu bibliotek w Europie i Stanach Zjednoczonych, „Nowa Biblioteka” nr 2(21), 75-100.

Dobija D. (red.) (2003), Pomiar i rozwój kapitału ludzkiego przedsiębiorstwa. Materiały na konferencje, Warszawa: PFPK.

Eberhart G. (2010), The Librarian's Book of Lists, Chicago: ALA.

Edvinsson L., Malone M.S. (2001), Kapitat intelektualny, tłum. M. Marcinkowska, Warszawa: Wydawnictwo Naukowe PWN.

Freeman A.M. (1993), The Measurement of Environmental and Resource Values, Washington DC: Resources for the Future.

Głowacka E. (2011), Badania wartości ekonomicznej usług biblioteczno-informacyjnych $i$ ich wplywu na otoczenie, „Biblioteka”, nr 15(24), 217-230.

Głowacka E. (2015), Kultura oceny w bibliotekach. Obszary, modele i metody badań jakości zasobów oraz ustug biblioteczno-informacyjnych, Toruń: Wydawnictwo Naukowe Uniwersytetu im. Mikołaja Kopernika.

Górny M. (1999), Ocena efektywności udostępniania informacji w bibliotekach naukowych, Poznań: Wydawnictwo Naukowe Uniwersytetu im. Adama Mickiewicza w Poznaniu.

Grygrowski D. (2014), Zwrot nakładu $z$ inwestowania w bibliotekę, „Przegląd Biblioteczny”, t. 82 , z. 2, 166-188.

Handa T.S. (2015), Role of Public Library in the Society and a Future Vision ICT Enabled Rendering of its Services with Special Context to India, ResearchGate, [dok. elektr.], dostęp online: https:// 
www.researchgate.net/publication/265202196_ROLE_OF_PUBLIC_LIBRARY_IN_THE_SOCIETY_AND_A_FUTURE_VISION_OF_ICT_ENABLED_RENDERING_OF_ITS_SERVICES_WITH_SPECIAL_CONTEXT_TO_INDIA_By [odczyt: 16 lipca 2018].

Juchnevič L. (2014), Library Roles in Changing Society, „Social Transformations in Contemporary Society", vol. 2, 120-130.

Kostera M. (2003), Antropologia organizacji. Metodologia badań terenowych, Warszawa: Wydawnictwo Naukowe PWN.

Król H. (2007), Kapitał ludzki organizacji, [w:] H. Król, A. Ludwiczyński (red.), Zarządzanie zasobami ludzkimi, Warszawa: Wydawnictwo Naukowe PWN, 92-119.

Krzyworzeka P. (2008), Kultura i organizacje: perspektywa antropologiczna, [w:] M. Kostera (red.), Nowe kierunki w zarzadzaniu, Warszawa: Wydawnictwa Profesjonalne i Akademickie, 181-197.

Krzyworzeka P. (2015), Etnografia, [w:] M. Kostera (red.), Metody badawcze w zarządzaniu humanistycznym, Warszawa: Wydawnictwo Akademickie Sedno, 27-36.

Masuda Y. (1983), The Role of the Library in the Information Society, „The Electronic Library”, vol. 1 , no. 2, 143-147.

Missingham R. (2005), Libraries and Economic Value: A Review of Recent Studies, „Performance Measurement and Metrics", vol. 6, no. 3, 142-158.

Osiewalski J., Osiewalska A. (2002), Ekonometryczne modelowanie kosztów polskich bibliotek publicznych, [dok. elektr.], dostęp online: http://www.ebib.pl/publikacje/matkonf/standardy/osie.php.

Penc J. (1997), Leksykon biznesu, Warszawa: Placet.

Prensky M. (2001), Digital Natives, Digital Immigrants, „On the Horizon”, vol. 9, no. 5

Prędki A. (2015), Pomiar efektywności kosztowej polskich bibliotek publicznych za pomoca metody DEA, „Studia Ekonomiczne. Zeszyty Naukowe Uniwersytetu Ekonomicznego w Katowicach", nr 235, 194-207.

Stewart T. A. (2001), The Wealth of Knowledge. Intellectual Capital and the Twenty-First Century Organization, London: Nicholas Brealey Publishing.

Wojciechowska M. (2006), Ocena skuteczności działalności biblioteki, „Przegląd Biblioteczny” nr 3, 319-335.

Willis K.G. (2014), The Use of Stated Preference Methods to Value Cultural Heritage, [w:] V. Ginsburgh, D. Throsby (ed.), Handbook of the Economics of Art and Culture, vol. 2, Oxford: Noth Holland, 145-181.

Wołosz J. (2002), Efektywna biblioteka publiczna w społeczeństwie informacyjnym, [dok. elektr.], dostęp online: http://www.ebib.pl/publikacje/matkonf/standardy/wolosz.php [odczyt: 21.09.2018].

Zybert E.B. (2005), Organizacyjna kultura jakości w bibliotekach, „Bibliotekarz”, nr 1, 2-8.

Ustawa z dnia 25 października 1991 r. o organizowaniu i prowadzeniu działalności kulturalnej, Dz.U. 1991 nr 114 poz. 49.

Ustawa z dnia 27 czerwca 1997 r. o bibliotekach, Dz.U. 1997 nr 85 poz. 539. 